\title{
Study on the Function and Influence of New Democratic Revolution for the Political Modernization of China
}

\author{
Juxiang Zhang \& Xia Jiang \\ School of Humanities, Law and Art, Changzhou University, Changzhou 213164, China \\ E-mail: zhangjx@cczu.edu.cn
}

The research is supported by the College Philosophical and Social Science Fund of Jiangsu Provincial Office of Education (No. 2010SJB710001). (Sponsoring information)

\begin{abstract}
There were many obstacles and difficulties for the political modernization in modern China, and the revolution was one way of the political development. The win of New Democratic Revolution provided the premise of the political modernization, and People's Democratic Dictatorship regime was the special mode of political modernization, which paved the way for the political development. However, in the revolution times, the construction of democratic politics could not been put on the first place, and the mass mobilization striving for the win of revolution had influenced the construction of democratic politics to some extent.
\end{abstract}

Keywords: New Democratic Revolution, Political modernization, Function and Influence

In the report of the CPC's Seventeenth Congress, "people's democracy is the life of socialism, and to develop the socialism democratic politics is and will be the unswerving objective and task for CPC". New Democratic Revolution created new China, and many development sources of new China had formed in the revolution times. The function and influence of New Democratic Revolution for the political modernization of China will be specially analyzed as follows.

\section{Main problems in the political modernization of modern China}

Political modernization is the important part of modernization, but after the modernization of China started, many factors blocked the change of Chinese government system from the tradition to the modern.

\subsection{Feudal autocracy blocked the political modernization}

Because of thousands years' feudal history, China had a set of tight feudal system and complete idea system and concept ideology. The main characteristic of feudalism is the autocracy, including the autocracy of power and the autocracy of culture. The power autocracy meant that the emperor was the highest governor, and the last decision right only belonged to the emperor. The bureaucracy was composed by the grading system, and the whole social power structure was based on the chain system of commission one layer by one layer, and in this system, there were no equality among people, but only personal possession and domination from up to down. This kind of personal possession relation formed the personal-oriented man system, with the extravagant hopes, pursuing, dependence, and worship of power, which induced that the consciousness of "official ranking" and "private rights" was strengthened, with the "upper and lower grade consciousness" and "narrow obedient ideas". The cultural autocracy begun from Qin Shi Huang's "burning books and burying Confucian scholars alive", and then there were Emperor Wu of Western Han's “ousted hundred and various rejection”, and in the Dynasty of Yuan, Confucian scholars were ranked at the ninth position, and the Dynasty of Ming made the Tung-Lin Faction event, and the Dynasty of Qing made numerous unjust cases in virtue of "literary inquisition". The dictatorship and privilege of the feudal autocracy obviously deviated from the modern political civilization, and blocked the modernization of Chinese politics.

\subsection{Imperialist aggression blocked the system change of the society}

Since the modern times, though the invasion of the capital-imperialism to China had unconsciously played the role of imputer and spreader of modern civilization, and objectively involved it into the tide of world modernization, but its intention absolutely was not to change feudal China to capitalistic China, but put the benefit of them into the raw material field and commodity market. Though it built the appearance of modernization, but lacked in the structured base of modernization. Big powers occupied lands, divided up sphere of influence, forcibly occupied leased territories, and enjoyed consular jurisdiction in China, which seriously harmed the sovereign rights and territorial integrities of China, weaken the resulting force of the state power to the country and the social mobilization and the strain to the external world, and blocked the systematic reform in China. "For the political stabilization of China, the invasion of the sovereign rights should be criticized. China had lost the control of its ports, trade, finance, and resident aliens, which were very difficult to compensate (Gilbert, Rozman, 2005, P.32)". Therefore, the imperialism invasion blocked the growth of various modernized factors in China, and it didn't help China to enter into modern 
society, but was one of main factors to block the modernization of China.

\subsection{The modernization of China needed powerful central government}

The development experiences of many modernization countries showed that powerful central government was one of important conditions to realize the modernization quickly. Taking Japan and Russian as examples, the governments all played very effective function to start the modernization, and "controlled foreign trade and highly developed communication transportation network, including controlling civil prices, and this control was few in the countries in the similar developing stage" (Gilbert, Rozman, 2005, 58). However, when the modernization of China started, the government of Qing had been in the political decay going from bad to worse, and the whole country had not been effectively controlled in the central government, and the important social reform had been unimaginable, even not the implementation of social reform. The late Qing government was hard to lead the course of modernization, which was the main cause to induce confusion, disorder, and inefficiency after the modernization of China was started. After the revolution of 1911, there was not enough powerful new authority, and the authority and resources of the Northern Warlord government still decentralized in local governments and folks. The social support of the Nanjing National government was extremely weak, and the authority of the central government had not been really established all the time, and with the corruption and the separation of the system, the modernization course of China was hard to be driven, but it was the obstacle for China to go to modernization.

\subsection{The modernization of China needed the core leading of a modern party}

The modernization needed the core leading of the modern party, and those modernized countries which had been or had been thought highly stabilized all had one powerful party at least. After the Second World War, the parties "had directly been the core of the political stage of Japan, and directly undertaken the important mission to lead the development of Japan modernization. The appearance of the 'Fifth Five-Year Plan Period System' taking the 'one-party parliament' of the Liberal Democratic Party as the basic sign not only marked the formation of the political and party situation in Japan, but marked the formation of the system that the parties directly leaded the modernization development of Japan (Lin, 1998, P.12-13)". However, in modern times, China had always lacked in powerful modern party to lead the modernization course. The Tung-meng Hui of China was the first real party in modern China, but as the political party of the bourgeois in the semi-colonial and semi-feudal society, it had not been a powerful party because of its representative class limpness and other deficiencies. In 1927, the Kuomintang based on the Tung-meng Hui obtained the ruling position in China, and the historical opportunity made it to lead the modernization course. However, Kuomintang lacked in the ability to innovate the system, and could not bring the social change into the frame of political system. With lower political institutionalization, its domination mainly depended on military power, but the force of arms could not be maintained for a long time. Therefore, the Kuomintang was not a powerful party, and it had not been the leading core of the modernization.

\section{New Democratic Revolution drove the development of the political modernization of China}

The revolution is a way of the political development, and New Democratic Revolution was a kind of anti-imperialist and anti-feudal revolution to strive for the national independence and the people libration, and it created the way for the political development and drove the course of the political modernization of China.

\subsection{National independence and people liberation provided the essential premise for the political modernization}

Since the CPC founded, it had always held up the anti-imperialist and anti-feudal flag, and the Second National Congress of CPC basically established the first democratic revolution program in the modern China. The National Revolution implemented by the Kuomintang-Communist cooperation toppled the autocratic dictatorship of the Northern Warlords, and provided the premise for the initial unity of the state power and the establishment of the single national power. After the Mukden Incident, holding up the anti-imperialist flag, the CPC established the strategy of the anti-Japanese national united front, and actively promoted and leaded the majority of people, farmers, petty bourgeoisie, and national bourgeoisie to join the anti-Japanese democratic movement. After the Lugouqiao Incident broke out, the anti-Japanese national united front based on the second Kuomintang-Communist cooperation normally came into existence, and the CPC played a tower of the strength in the war of resistance against aggression. The victory of the war of resistance against aggression was the turning point of the Chinese history, and it offered the opportunity for the construction of the modernization. To realize the peace, the CPC paid unremitting efforts, but to establish the national autocracy in China, the Kuomintang brazenly tore up the resolution of the political consultative conference and the cessation of hostilities, and provoked the comprehensive civil war with the large support of US, and the CPC organized and leaded the national people to implemented the patriotic and just war. The establishment of the new China signed the great victory of the anti-imperialist and anti-feudal new-democratic revolution, and ended the national survival crisis and political regression ruining the state and destroying the race, eliminated the main obstacle of the political modernization, and created the essential premise of the political modernization. 


\subsection{The establishment of People's Democratic Dictatorship state power paved the way for the political development}

The state power of People's Democratic Dictatorship established by the CPC through long-term exploration in the New Democratic Revolution term was different with the occidental dictatorship of the bourgeoisie, and the dictatorship of the proletariat from the Soviet Union, and it was the special mode of political modernization according with the national situation of China, which developed the way for the political modernization. First, it promoted the development of the Chinese democracy. The modern china didn't maintain of the democratic rights, but strived for the democratic rights. The establishment of the state power of People's Democratic Dictatorship firstly confirmed the democracy from the meaning of the state system, and the main body of the democracy was extended to the whole people in China, so the political development of China possessed deep base and firm power firstly. Second, it established the base for the political development of China on the socialism way. The generation of the bourgeois democracy was the important result in the development of the human political civilization, but it covered the inequality from the equality of the form, with certain falsity and fraudulence. The socialist democracy was the modern political civilization which was higher than the bourgeois democracy, and People's Democratic Dictatorship was the proletariat power in essential, and with the transfer from the new-democratic society to the socialist society, the state power also changed from the new-democratic power to the socialist power, and the political development of China stepped on the socialist way. Third, it extended the range of the democracy. In the process to establish the state power of People's Democratic Dictatorship, the CPC creatively dealt with the antagonistic contradiction between the working class and the national bourgeoisie as the contradiction among the people, and continually kept the economic union and the political union with the national bourgeoisie in the initial stage of founding the state, and accordingly extended the range of the people democracy.

\subsection{The conformation of the leader status of CPC provided the political guarantee for the political modernization}

The support of the people could create the real political power, and the CPC early realized that the real impregnable fortress was the people, and the millions of people who supported the revolution genuinely and sincerely. In virtue of the policy of protecting the national industry and commerce, the CPC obtained the support of the national bourgeoisie. After the "May One Call", many democratic parties, mass organizations, and patriotic democratic personages expressed that they would support the suggestions of the CPC and response the opinions of the CPC, and enter into the liberation area to prepare the new political consultative conference. China was the big country of agriculture, and the farmers were oppressed most heavily, and the CPC made farmers to live and work in peace and contentment by the land reform, and the farmers would actively become the continual power to reform the old production relations. Just by this right political leading and careful people work, the CPC gradually established its leading state. According to the basic Marxism theories, the proletariat was the most advanced class in the modern society, and it could embody the spirit of modernization most, and it would be the leading class of the modernization with the development of the big industry. The CPC was the advanced represent of the proletariat in China, and it possessed bright modernization orientation when it was founded, and it tried to establish the new state power by the social revolution, and create necessary premise and base for the modernization. The conformation of the leading state of the CPC provided the political guarantee for the political modernization. The experiences of the modern history showed that "without the efforts of the $\mathrm{CPC}$, without the mainstay of the CPC members in Chinese people, the independence and liberation of China was impossible, and the industrialization of the industry and the modernization of the agriculture were also impossible" (Mao, 1991, P.1098).

\section{Analysis of the influences of New Democratic Revolution mobilization mode}

The ruthlessness and the tough characteristic of New Democratic Revolution determined that the CPC could not put the construction of the democratic policy on the first position at that time, and the mass mobilization striving for the victory of the revolution also impacted the construction of the democratic construction in certain conditions.

\subsection{To strive for democracy is the important flag to mobilize the mass}

In the term of New Democratic Revolution, the first task of the CPC was to realize the national independence and the people libration and establish the uniform central government. However, the enemies of the Chinese revolution included not only strong imperialism and feudal forces, but also the bourgeois reactionaries colluding with imperialism and feudal forces in a certain period, which induced the protracted nature and the ruthlessness of the Chinese revolution. To strive for the victory of the revolution, all works revolved around the revolution war, and from the Second National Congress of CPC when the CPC put forward unifying China as the real democratic republic, to strive for the democratic rights became the bright flag for the CPC to mobilize the masses, and became the sharp weapons to win the enemy. To strive for the democracy played a very important role to mobilize the people to join the army, join the war, support the front, implement the land reform, the economic construction, improve the people's life, and guarantee the victory of the revolution war, and it was one important cause of CPC to become strong from weak, and turn the tables, and finally win the state power. However, just as that, the CPC could not put 
the construction of the democratic politics on the first position, and the construction of the democratic politics and the political participation and attempts were initial and immature at that time. For example, in early 1927, the CPC put forward taking the people represent congress as the power organization form, but "the execution committees of the government of the so-called council of workers, peasants, and soldiers from the village, the town to the county level, were all elected by one way like the people meeting, and this kind of meeting could not solve problems and train the people in politics" (Mao, 1991, P.72). This situation not only existed in the base area of Jinggang Mountain, but also in other base areas.

\subsection{Double effect of mass movement}

New Democratic Revolution was "the war of people' s, and only to mobilize and depend on the people, could we carry on the war" (Mao, 1991, P.136). As the important form to mobilize the people, the mass movement in the revolution term was the magic weapon to win the enemy, and the CPC constituted a set of policies about the mass movement in the practice. The mass movement recalled the people's political enthusiasm and enhanced their political consciousness, and millions of people supported the revolution with highly rising political enthusiasm and participation consciousness from the human resources, the material resources, and the financial resources to defend the victory. The CPC just mobilized and organized millions of people to win the democratic revolution. However, the mass movement was in a kind of abnormal state, with short-term material gains, it easily caused intemperate actions, sectarianism, and false enthusiasm. The mass movement easily made people misunderstands the democracy, and simply understood the democracy as "that the people are the masters of the country". This kind of simple movement-type "democracy" avoided the system and program of the democratic politics, and it was largely different with the democratic politics. The democratic politics should be based on the rule of law, but the movement-type "democracy" could only promote the rule of man, and it could not really lighten the people's democratic consciousness. Later, the crooked way in the democratic construction of China was absolutely associated with this movement-type "democracy".

\subsection{Two consequences of the route struggle in the CPC}

In New Democratic Revolution term, the CPC made the mistakes of the "left deviation" or the "right deviation" many times in political line's understanding, the revolution was damaged heavily. Obviously, if these mistakes were not corrected, the Chinese revolution would be ruined. At that time, not only the mistakes should be corrected, but also the will of the CPC should be highly centralized in the shortest time, and the long-term disputes should be avoided. Therefore, to clean up various non-proletarian ideologies and consolidate the $\mathrm{CPC}$, the route fight in the CPC would be the way to unify the will in the CPC, which was completely necessary and unavoidable. It should be affirmed that the route fight in the CPC at that time had been effective, and the criticisms about various mistakes were serious and profound, and the CPC stopped many mistakes and highly unify the opinions and will in the CPC by the interior route fight, and accordingly guarantee the high-effective leading and the victory of the revolution. However, this form had double effects for the democratic politics, which should not be neglected. Because the existing time of the CPC was short, and the theoretical level of the CPC members was lower, and the experiences were not sufficient, and the democratic life in the $\mathrm{CPC}$ was not normal, many counterrevolutionaries entered into the $\mathrm{CPC}$ to destroy the party. The interior route fight begun to deviate, including the liberalism, the mechanical and ham fight, and the disputes and fights without rules. These deviations gradually eliminated the criticism and self-criticism spirit in the CPC, promoted the development of the patriarchal system, extreme democratic tendency, and the liberalism, and induced the abnormal and unusual democratic life in the CPC. The nervous social and political air induced by these problems would easily make the people to lose the political enthusiasm and participation consciousness, which would all influence the construction of the democratic politics to some extent.

To sum up, the semi-colonial and semi-feudal national situation blocked the political modernization of the modern China, and New Democratic Revolution solved many problems in the political modernization, and promoted the development of the political modernization. At the same time, the mass movement adopted in that term to win the revolution was also disharmonious with the development of the democratic politics. How to avoid these disharmonious factors was the key to win the construction of the political modernization, which had been fully proved by the construction of the democratic politics after the new China being founded.

\section{References}

Gilbert, Rozman. (2005). The Modernization of China. Nanjing: Jiangsu People’s Publishing House. P.32 \& 58.

Lin, Shangli. (1998). Party Politics and Modernization. Shanghai: Shanghai People's Publishing House. P.12-13.

Mao, Zedong. (1991). Selected Works of Mao Tse-tung (Volume 3). Beijing: People's Publishing House. P.1098.

Mao, Zedong. (1991). Selected Works of Mao Tse-tung (Volume 1). Beijing: People's Publishing House. P.72 \& 136. 